relevante y aportar las novedades que él mismo aporta, como la etimología del término ayra.

El resto del libro consiste en la transcripción de los documentos (pp. 41348). Los criterios para llevarla a cabo parecen los más adecuados. Así, se evita hacer una transcripción paleográfica que recoja todos los pormenores formales, y que llevaría a una lectura farragosa de los documentos. El autor opta por recoger los cambios de renglón y de folio y mantener la ortografía original, pero introduce a su vez las tildes y usa la mayúsculas y minúsculas conforme a las reglas actuales de la lengua española. De este modo se consigue una lectura fácil y fluida, a la vez que mantiene el estilo del español del siglo XVI.

Otro aspecto que se debe destacar de esta edición es la inclusión de índices al final del libro: toponímico, onomástico y de huacas (pp. 349-382). De esta forma, el lector tiene a su disposición una excelente edición documental que le permite buscar información de primera mano sobre este célebre movimiento andino.

Guillermo Arquero

\title{
Ricardo Silva-Santisteban (2018). Escrito en el agua. Tercera edición. Lima, Alastor Editores, 570 pp.
}

El poeta se encuentra en la incesante búsqueda de un lenguaje original. La musicalidad, el ritmo, la métrica, con pinceladas de sensibilidad, lo acompañarán para trastocar las fibras del espíritu del lector. A estos aspectos elementales, el creador necesita reconocer la tradición literaria, valorarla para renovarse constantemente por las sendas de la creación. Con esa aguda mirada selecciona autores imprescindibles, rescata discursos olvidados y, si la oportunidad se le da, critica con fineza los logros alcanzados por cada artista. Incluso, ese hálito poético lo lleva a traducir poemas con destreza a fin de mantener la originalidad de los versos. Pocos logran conciliar e integrar esas virtudes como el autor de Escrito en el agua.

El profesor universitario, crítico literario, poeta, editor y traductor Ricardo Silva-Santisteban ha publicado por tercera vez el mencionado libro bajo el sello de Alastor Editores. Su prosa nos invita a descubrir las melódicas y notables expresiones de la poesía universal. Esta invitación recorre y comprende la creación poética. En «Meditación acerca de la poesía y la existencia», inédito texto de una serie de treinta y tres disertaciones establece que el empleo del lenguaje constituye un componente imprescindible para el poeta, pues le permite capturar y mostrar una esencia del cosmos. Ese instinto comunicativo, producto de las lecturas heredadas, experiencias e intuiciones, lo representa y le permite trazar imágenes de notable efecto rítmico. «Los poetas logran una creación poé-

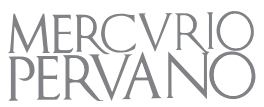


tica significativa, en la medida en que colman, mediante naturalidad y artificio, su expresión y su arte» (p. 15). Queda, entonces, justificada la selección de los testimonios verbales, cánticos admirables de seres que experimentaron el estupor de la vida y lo condensaron en poemas que traspasan épocas.

Desde Safo hasta Louis Aragon, pasando por los poetas más emblemáticos como Horacio, Shakespeare, Hölderlin, Pushkin, los simbolistas franceses, T. S. Eliot, entre otros creadores de expresiones eternas, desfilan progresivamente bajo el despliegue de una prosa musical y profunda. Así, Ricardo Silva-Santisteban nos deslumbra con sus interpretaciones producto de largas meditaciones y relecturas que le permite recomponer el proceso misterioso de la creación escritural, como lo reconoce al encontrarse ante la genialidad de los versos de Rimbaud: "Cuando el poeta irrumpe en la poesía lo hace dueño ya de sus medios expresivos» (p. 439). Esa mirada personal propone una reflexión sobre el canto y el sacrificio, justificando las obras y a los poetas, cimientos de una poética universal. Al respecto, uno de los aportes del libro es el rescate de los textos de la época colonial brasileña para un replanteamiento crítico. De ese modo, resalta la originalidad, la calidad de los poemas producidos en dicho periodo, sobre los estudios basados en el prejuicio de la imitación.

En cuanto a la virtud de la faceta de traductor, encontramos el caso de la expresión poética de Li Tai Po. La comprensión de la cultura y cosmovisión oriental permite conservar el arte pictórico de los ideogramas hacia los versos castellanos cuya emoción se transmite en imágenes; de esa manera, la traducción comprende una remodelación de los conceptos orientales en el asidero castellano. En el caso de Mallarmé, de innegable espíritu estético, su traducción es compleja, ya que contiene una musicalidad que resuena con prestigiosa imaginación; sin embargo, la paciencia y la concentración logra ajustar el sentido de las producciones del poeta francés: «En castellano tenemos que contentarnos con aproximaciones» (p. 401).

Finalmente, Escrito en el agua nos ofrece un recorrido de constantes lecturas, donde el compromiso del crítico y poeta logra orientar al lector. El libro sirve de brújula literaria donde el objetivo es la trascendencia de la sensibilidad más allá de la barrera del idioma y que la traducción otorga una oportunidad para compartir el arte poético de los autores más representativos. Por consiguiente, las anotaciones y los comentarios, nos ayudan a reflexionar sobre la crítica, la historia literaria, la cultura y la poética. Ricardo Silva-Santisteban viene a ser ese Prometeo que recoge los conocimientos ancestrales, es ese Virgilio que nos acompaña y sirve de guía hacia la verdad de la Poesía.

Williams Nicks Ventura Vásquez 